Egyptian Journal of Aquatic Biology \& Fisheries

Zoology Department, Faculty of Science,

Ain Shams University, Cairo, Egypt.

ISSN $1110-6131$

Vol. 25(3): 713 - 738 (2021)

www.ejabf.journals.ekb.eg

\title{
Inhibitory effect of nano selenium on the recurrence of Aeromonas hydrophila
} bacteria in Cyprinus carpio

\author{
Ahmed H. Sherif ${ }^{1 *}$, Mofeed Y. Gouda ${ }^{2}$, Mohsen A. Zommara ${ }^{3}$, Abeer H. Abd El-Rahim ${ }^{4}$, \\ Karima F. Mahrous ${ }^{4}$, Soad S. Abd-El halim Salama ${ }^{5}$ \\ ${ }^{1}$ Fish Diseases Department, Animal Health Research Institute, Agriculture Research Center \\ ARC, Kafrelsheikh, 12619 Egypt \\ 2 Pathology Department, Animal Health Research Institute AHRI Agriculture Research Center \\ ARC, 12619Egypt \\ ${ }^{3}$ Dairy sciences Department, Faculty of Agriculture, Kafrelsheikh University, 33511 Egypt \\ ${ }^{4}$ Cell Biology Department, Genetic Engineering and Biotechnology Division Research, National \\ Research Centre, Giza, 12622 Egypt \\ ${ }^{5}$ Fish Diseases Research Department, Animal Health Research Institute, AHRI, Agriculture \\ Research Center ARC, Dokki, 12619 Egypt \\ *Corresponding Author: ahsherif77@yahoo.com
}

\section{ARTICLE INFO}

Article History:

Received: April 14, 2021

Accepted: May 26, 2021

Online: June 28, 2021

Keywords:

Cyprinus carpio;

Selenium nanoparticles;

Cytokines;

Aeromonas hydrophila;

Antioxidant enzymes

\section{ABSTRACT}

The recurrence of bacterial infection in fish is related to several factors, including the immune status and oxidative state. A total number of 240 Cyprinus carpio was divided into four treatments; control (T1) fed on free diet and three treatments (T2-4) fed on supplemented diet with nanoparticles of selenium Se NPs $(1 \mathrm{mg} / \mathrm{kg}$ fish feed) for 10, 20, and 30 days, respectively. Supplemented fish with Se NPs for 30 days (T4) had significantly higher total protein and globulin content (5.83 and $3.1 \mathrm{~g} / \mathrm{dl}$, respectively) compared to the control indicating an enhanced immune status. Fish fed on Se NPs supplementation for 30 days (T4) recorded significantly higher anti-inflammatory cytokine "interleukin (IL)-10", while the pro-inflammatory cytokines "tumour necrosis factor (TNF)- $\alpha$, IL-1 $\beta$, and IL- 8 " reduced significantly compared to the control. Antioxidant enzymes (glutathione peroxidase GPx, catalase CAT, and superoxide dismutase SOD) were gradually and significantly enhanced in time-dependent manner. Genotoxicity (DNA damages, DNA fragmentation, and presence of micronuclei) was low in supplemented fish while challenged fish performed in an opposite manner. However, Se NPs supplementation had overcome those withdraws causing a decrease in the signs of genotoxicity. Se NPs improved the immunity, antioxidant, and histopathological status of $C$. carpio showing enhancements in disease resistance, as reducing the chance of recurrence of Aeromonas hydrophila infection and genotoxicity.

\section{INTRODUCTION}

Aquaculture produces about $42.2 \%$ of the global world's production of fish in 2016 which represents $50 \%$ of the fish consumption; fish and fish products are the key to meet the need for protein concerning human nutrition in Egypt (FAO, 2018). 
Selenium (Se) is a vital trace mineral that plays an important role in animal metabolism saving the antioxidant state and immune status (Yu et al., 2014; BillerTakahashi et al., 2015; Zhang et al., 2017). The nutritional requirements of selenium were estimated in different fish species; Nile tilapia (Oreochromis niloticus; 1.06-2.06 $\mathrm{mg} / \mathrm{kg}$ ) (Lee et al., 2016), and the gibel carp (Carassius auratus gibelio var. CAS III; $0.73-1.19 \mathrm{mg} / \mathrm{kg}$ ) (Zhu et al., 2017). To optimize the antioxidative state of rainbow trout (oncorhynchus mykiss) fry, the supplementation of Se was recommended to be added to the plant-based diets (Fontagné-Dicharry et al. 2015). Under stress conditions, damages of the cell membrane, protein, and DNA of the animal cells are due to the formation of free radicals (Halliwell, 2006; Kumar et al., 2018). As a part of antioxidant enzymes, Se protects the cell membranes and cellular components from the impacts of oxidative stresses (Liu et al 2004). Se nanoparticles (Se NPs) is less toxic and safer than inorganic Se (Forootanfar et al., 2014; Kumar et al. 2018), it also enhances the immune responses and antioxidant activity in common carp (Cyprinus carpio) (Saffari et al., 2018) and $O$. mykiss Kohshahi et al. (2019).

Fish pathologists are using tremendous amounts of antibiotics and disinfectants to control fish diseases that resulted in the emergence of antibiotic-resistant bacteria (Abutbul et al., 2004; Sherif et al., 2021a). Additionally, Se NPs supplementation enhances fish resistance against bacterial infection; Xia et al. (2019) noticed that zebrafish (Danio rerio) fed on Se NPs at a dose of $10 \mu \mathrm{g} / \mathrm{g}$ had a higher survival rate compared to the control group after challenging against $A$. hydrophila.

To study the genotoxicity of any material in water and/or fish, chromosomes are the best choice (Parveen $\boldsymbol{\&}$ Shadab 2012) and the comet assay is a reliable test to confirm DNA damage (de Andrade et al., 2004).

The purpose of this study is to assess the potential role of Se NPs in decreasing the recurrence of bacterial infection in C. carpio through studying the influence of Se NPs on the immunity, antioxidant activity, and genotoxicity besides a trial of isolation of pathogenic bacteria from survived fish after different periods.

\section{MATERIALS AND METHODS}

\subsection{Fish sampling, accommodation, and experimental design}

A total number of 260 Cyprinus carpio $(5 \pm 0.1 \mathrm{~g}$ b.w.) was collected from a local private freshwater fish farm at Tolompate 7 Village, Kafrelsheikh Governorate, Egypt, and were stocked in the wet laboratory of Animal Health Research Institute (AHRI). Fish were acclimated in a fibre-glass tank $(3 \times 1.5 \times 1 \mathrm{~m})$ for two weeks. Afterwards, 20 fish specimens were subjected to clinical and post-mortem analyses following the methods described by Austin and Austin (2012) to make sure that the fish were free of any diseases. Fish $(n=240)$ were divided equally and randomly into four treatments $(\mathrm{T} 1-4)$; each treatment had three replicates (20 fish / glass aquarium). The first presented the 
control (T1) fed on a free diet, while the second (T2), the third (T3), and the fourth (T4) were fed on supplemented-Se NPs diet at a dose of $1 \mathrm{mg} / \mathrm{kg}$ fish feed for 10, 20, and 30 days, respectively. Fish were fed on a formulated diet (CP 38\% and digestible energy $2954 \mathrm{Kcal} / \mathrm{Kg}$ ) twice daily with $5 \%$ of their weights for six days per week. Water parameters of tank and glass aquaria $(110 \times 50 \times 50 \mathrm{~cm})$ were maintained in suitable condition for fish culture (temperature $28 \pm 1{ }^{\circ} \mathrm{C}$, dissolved oxygen $\geq 5.5 \mathrm{mg} / 1, \mathrm{pH} 7.8$ and salinity $\leq 0.3 \mathrm{~g} / \mathrm{l}$ ), also one-third of water was daily exchanged with fresh water to keep water quality and remove solid discharges.

\subsection{Source of nano-selenium spheres and diet preparation}

Se NPs were manufactured following the methods described by Zommara (2007) and Prokisch et al. (2008) using lactic acid bacteria (LAB-Se, Lactomicrosel $®$ ). Briefly, Se NPs were manufactured from pure yoghurt cultures of Streptococcus thermophilus (CNCM I-1670) and Lactobacillus delbrueckii subsp. bulgaricus (NCAIM B 02206). The size of the obtained Se NPs was within the range of $100-500 \mathrm{~nm}$, the characterization of Se NPs was performed using inductively coupled plasma mass spectrometer (ICP-MS) (X series, THERMO FISHER SCIENTIFIC, Germany) (Eszenyi et al., 2011; Prokisch et al., 2011).

Firstly, Se NPs were ultrasonically distributed in Milli-Q water (1 $\mathrm{mg} / \mathrm{ml})$ according to the procedure developed by Lammel and Sturve (2018), Thereafter, fish food (pellet form) was soaked and fully homogenated till paste formation. Then, the gelatine was added to feed past/ Se NPs mixture to improve feed consistency (Canal Aqua Cure, Egypt) and left to dry at room temperature then was evenly cut into small size.

\subsection{Bacterial infection}

After the feeding trial, fish (50 fish/treatment) was experimentally subjected to bacterial infection with Aeromonas hydrophila (AHRAS2, accession number in NCBI is MW092007. Fish was injected via intraperitoneal route with $\mathrm{LD}_{50}\left(2.4 \times 10^{5} \mathrm{CFU}\right)$ according to methods described by Schaperclaus $\boldsymbol{e t}$ al. (1992). The number of dead fish was recorded for 14 days, and cumulative mortality rate (CMR) was measured using the following equation:

CMR $(\%)=($ number of deaths in a specific period / total population during that period) $\times 100$.

After 14 days of bacterial infection, the survived fish was bacteriologically examined for A. hydrophila. Three attempts of bacterial isolation were performed with a week interval. Bacterial isolation was done using five fish randomly selected from each treatment group. Samples for bacteriological analyses were collected from skin lesions, kidneys, heart, liver, spleen, and gills and inoculated onto brain heart infusion agar (BHIB) and incubated at $28^{\circ} \mathrm{C}$ for $24 \mathrm{~h}$ (Tonguthai et al., 1999). Pure colonies streaked onto Rimler's- Shotts medium (RS medium), Aeromonas selective agar base with ampicillin supplement, XLD media. All cultures were incubated at $28{ }^{\circ} \mathrm{C}$ for $24 \mathrm{~h}$, and 
characterization of isolated bacteria was recorded. Phenotypic characterization of the bacterial isolates was confirmed according to Bergey (1994), Elmer et al. (1997) and Madigan and Martinko (2005). All isolates were identified biochemically by using API 20E strips (Bio-merieux, 1984).

\subsection{Cytokines of the experimental $C$. carpio}

Interleukin $1 \beta$ (IL-1 $\beta), T N F-\alpha$, and IL-10 were measured in the serum of $C$. carpio by ELISA (enzyme-linked immunosorbent assay) using a solid-phase sandwich ELISA test kit obtained from (My BioSource Co., San Diego, California, USA). The procedures were done following the manufacturer's instructions.

\subsection{Total protein and globulin fractions}

The concentration of serum total protein (TP) (Weichsellbaum, 1946) and albumin (ALB) (Doumas et al., 1971) were measured by colorimetric methods. While serum globulin concentrations (GLO) were calculated by subtracting the concentration of TP from ALB concentration. The electrophoretic pattern of serum protein fractions was measured using polyacrylamide gel columns (Maurer, 2011). Moreover, the gel was scanned and read according to Glick (1968).

\subsection{The activity of antioxidant enzymes}

The activity of glutathione peroxidase (GPx) (EC 1.11.1.9) in the liver of $C$. carpio was determined according to the method described by Anderson and Greenwald (1985). The contents of reaction mixture were $1.44 \mathrm{ml}$ of $0.05 \mathrm{M}$ PBS (pH 7.0), $0.1 \mathrm{ml}$ of $1 \mathrm{mM}$ EDTA, $0.1 \mathrm{mM}$ sodium azide, $0.05 \mathrm{ml}$ of glutathione reductase (GR; $1 \mathrm{U} / \mathrm{ml}$ ), 0.1 $\mathrm{ml}$ of $1 \mathrm{mM}$ glutathione (GSH), $0.1 \mathrm{ml}$ of $2 \mathrm{mM} \mathrm{NADPH}, 0.01 \mathrm{ml}$ of $0.25 \mathrm{mM} \mathrm{H}_{2} \mathrm{O}_{2}$ and $0.1 \mathrm{ml}$ of $10 \%$ PMS in a total volume of $2 \mathrm{ml}$. The disappearance of NADPH was recorded using a spectrophotometer at $340 \mathrm{~nm}$. Enzyme activity was expressed as nmol NADP reduced $/ \mathrm{min} / \mathrm{mg}$ protein using a molar extinction coefficient of $6.22 \times 103 / \mathrm{M} / \mathrm{cm}$. Catalase CAT (EC 1.11.1.6) activity in the liver of $C$. carpio was determined spectrophotometrically at $240 \mathrm{~nm}$ and calculated as $\mu \mathrm{mol} \mathrm{H}_{2} \mathrm{O}_{2}$ decomposed/ $\mathrm{mg}$ protein/min following a method developed by Anderson and Greenwald (1985). Superoxide dismutase SOD (EC 1.15.1.1) activity in hepatic tissue was measured using the auto-oxidation principle of pyrogallol, which is inhibited in the presence of SOD. The optical density change was determined kinetically for 2 min at $420 \mathrm{~nm}$, at 10 -second intervals, according to the method mentioned by Beutler (1984). Activities of antioxidant enzymes were measured as $\mathrm{U} \mathrm{mg} / \mathrm{protein}$.

2.7 Genotoxicity of the experimental $C$. carpio

2.7.1 The comet assay

Comet assay was performed referring to the procedure developed by Blasiak $\boldsymbol{e t}$ al. (2004). Hepatic cells of fish were mixed with low-melting-point agarose (ratio of $1: 10 \mathrm{v} / \mathrm{v})$, then pipetted to precoated slides with normal-melting-point agarose. The slides were kept flat at $4^{\circ} \mathrm{C}$ for $30 \mathrm{~min}$ in dark condition. The third layer of low melting point agarose was pipetted onto the slides and was left to solidify $\left(4^{\circ} \mathrm{C}\right.$ for $\left.30 \mathrm{~min}\right)$. The 
slides were shifted to pre-chilled lysis solution, kept for 60 min at $4^{\circ} \mathrm{C}$, after that, slides were immersed in freshly prepared alkaline unwinding solution at room temperature in the dark for $60 \mathrm{~min}$. Slides were exposed to electrophoresis run at $0.8 \mathrm{~V} / \mathrm{cm}, 300 \mathrm{mAmps}$ at $4{ }^{\circ} \mathrm{C}$ for $30 \mathrm{~min}$. The slides were rinsed in neutralizing solution followed by immersion in $70 \%$ ethanol and then air-dried. The slides were stained with ethidium bromide and then visualized using Zeiss epifluorescence microscope (510-560 nm, barrier filter 590 $\mathrm{nm})$ with a magnification power of $\times 400.100$ cells per fish were scored. DNA damages were analysed using software (Comet Score, TriTek corp., Sumerduck, VA22742; Collins et al. (1997).

\subsubsection{DNA fragmentation assay}

The rates of DNA fragmentation were done following the methods used by Yawata et al. (1998). Briefly, hepatic tissues of C. carpio, treated with Se NPs and/ or infected with pathogenic bacteria, were homogenized in saline $(0.09 \% \mathrm{v} / \mathrm{v})$. The harvested cells (plus floating cells) were washed with Dulbecco`s phosphate-buffered saline then, cells were lysed using the lysis buffer [10 mM Tris ( $\mathrm{pH} 7.4$ ), $150 \mathrm{mM} \mathrm{NaCl}, 5 \mathrm{mM}$ ethylene diamine tetraacetic acid (EDTA), and $0.5 \%$ Triton X-100] for $30 \mathrm{~min}$ on ice. Lysates products were vortexed and cleared by centrifugation at $10,000 \mathrm{~g}$ for $20 \mathrm{~min}$. Fragmented DNA in the supernatant was extracted with an equal volume of neutral phenol:chloroform:isoamyl alcohol mixture (25:24:1) and analyzed electrophoretically on $2 \%$ agarose gels containing $0.1 \mu \mathrm{g} / \mathrm{ml}$ ethidium bromide.

\subsubsection{Micronuclei Test}

The presence of micronuclei was confirmed according to the method described by AL-Sabti and Metcalfe (1995). Briefly, the peripheral blood was obtained from the caudal vein of each fish, then smeared immediately after mixing with foetal calf serum and fixed in absolute methanol, and hence, dried in air. The slides were stained with Giemsa stain and observed under a microscope (Magnification $1000 \mathrm{X}$ ). Finally, the frequency of micronuclei was calculated in 2000 cells per individuals by using the following formula:

MN frequency $(\%)=($ Number of cells with Micronuclei $/$ Total number of cells counted) $\times 100$

\subsection{Histopathological Investigations}

For histopathological analyses of experimental fish, samples were collected from three tissues liver, kidney, and spleen before and after the bacterial challenge test. Formalin-fixed paraffin-embedded sections were processed routinely for H\&E staining according to methods described by Suvarna et al. (2012).

\subsection{Statistical Analyses:}

The impacts of Se NPs in C. carpio were statically analyzed with SPSS software for windows, SPSS Inc., Chicago, IL, USA (SPSS 2004) using analysis of variance (ANOVA). All values were expressed as the mean \pm SE (standard error). Duncan's 
multiple range test (Duncan 1955) was used to determine differences among treatments at a significance level of 0.05 .

\subsection{The applied biosafety measures}

This study followed the biosafety measures concerning the pathogen safety data sheets: Infectious substances- A. hydrophila, Pathogen Regulation Directorate, Public Health Agency of Canada (2010).

\section{RESULTS}

During the experimental period, the water parameters were maintained in a suitable range for $C$. carpio; water temperature $28 \pm 1{ }^{\circ} \mathrm{C}$, dissolved oxygen $\geq 5.6 \pm 0.5 \mathrm{mg} / \mathrm{l}, \mathrm{pH}$ $8.2 \pm 0.6$ and salinity $\leq 0.3 \mathrm{~g} / 1$.

\subsection{Challenge experimental fish with $A$. hydrophila bacteria}

A fifty $C$. carpio from each treatment was experimentally infected with $\mathrm{LD}_{50}$ of $A$. hydrophia to assess the immunostimulant properties of Se NPs. The survival of fish (Table 1) was gradually and positively increased with Se NPs. In Table (1), challenged C. carpio in T4, fed on Se NPs for 30 days resisted the bacterial infection and their survival rate was higher (37 out of 50) compared with the control (T1) (24 out 50 fish) (p $<0.05)$. A five $C$. carpio from each treatment was bacterially examined for the presence of $A$. hydrophia after a two-week period of the challenge test. The isolation rate of $A$. hydrophia was gradually decreased in a time-dependent of Se NPs supplementation. In T4, which received Se NPs for 30 days, A. hydrophia was not isolated after 4 weeks of infection.

Table 1: Mortality and infection rates of $C$. carpio Challenge with $A$. hydrophila

\begin{tabular}{|l|c|c|c|c|c|c|c|c|}
\hline \multirow{2}{*}{ Item } & \multicolumn{2}{|c|}{ T1 (Control) } & \multicolumn{2}{l|}{ T2 (10 day) } & \multicolumn{2}{l|}{ T3 (20 day) } & \multicolumn{2}{c|}{ T4 (30 day) } \\
\cline { 2 - 9 } & no. & $\%$ & no. & $\%$ & no. & $\%$ & no. & $\%$ \\
\hline Fish & $\mathbf{5 0}$ & - & $\mathbf{5 0}$ & - & $\mathbf{5 0}$ & - & $\mathbf{5 0}$ & - \\
\hline CMR & $\mathbf{2 6}$ & $\mathbf{5 2}$ & $\mathbf{2 4}$ & $\mathbf{4 8}$ & $\mathbf{2 0}$ & $\mathbf{4 0}$ & $\mathbf{1 3}$ & $\mathbf{2 6}$ \\
\hline Sur. & $\mathbf{2 4}$ & $\mathbf{4 8}$ & $\mathbf{2 6}$ & $\mathbf{5 2}$ & $\mathbf{3 0}$ & $\mathbf{6 0}$ & $\mathbf{3 7}$ & $\mathbf{7 4}$ \\
\hline Exa. & 15 & - & 15 & - & 15 & - & 15 & - \\
\hline Inf. Post 3 weeks & 3 & $\mathbf{6 0}$ & $\mathbf{3}$ & $\mathbf{6 0}$ & $\mathbf{3}$ & $\mathbf{6 0}$ & $\mathbf{2}$ & $\mathbf{4 0}$ \\
\hline Inf. Post 4 weeks & $\mathbf{3}$ & $\mathbf{6 0}$ & $\mathbf{3}$ & $\mathbf{6 0}$ & $\mathbf{1}$ & $\mathbf{2 0}$ & $\mathbf{0}$ & $\mathbf{0}$ \\
\hline Inf. Post 5 weeks & $\mathbf{2}$ & $\mathbf{4 0}$ & $\mathbf{1}$ & $\mathbf{2 0}$ & $\mathbf{1}$ & $\mathbf{2 0}$ & $\mathbf{0}$ & $\mathbf{0}$ \\
\hline
\end{tabular}

Treatments; T1: control; T2: supplemented Se NPs 10 days; T3: supplemented Se NPs 20 days; T4: supplemented Se NPs 30 days. no.: fish number; CMR: cummlative mortality rate; Sur.: survived fish; Exa: examined fish in last 3 weeks; Inf: infection rate. 


\subsection{Alteration of inflammatory cytokines in experimental fish}

As shown in Fig. (1), the cytokines were significantly affected with the addition of Se NPs to the $C$. carpio diet. Anti-inflammatory cytokine IL-10 was significantly increased $(\mathrm{P}<0.05)$ in serum of $C$. carpio in $\mathrm{T} 2, \mathrm{~T} 3$, and $\mathrm{T} 4$ treatments compared with the control 14.01, 15.51, and $19.89 \mathrm{pg} / \mathrm{mg}$, respectively. Pro-inflammatory cytokines TNF $-\alpha$, IL-1 $\beta$, and IL- 8 were significantly decreased with time in T2-T4 treatments compared to the control treatment $(4,1.55$, and $3 \mathrm{pg} / \mathrm{mg}$, respectively).

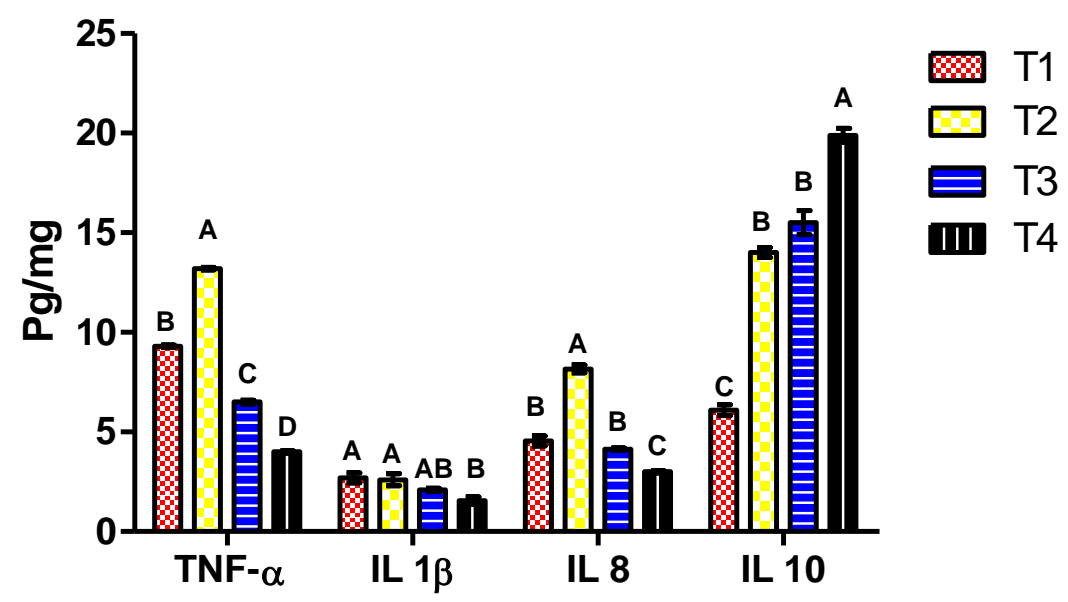

Fig. 1: Cytokines changes in serum of C. carpio.

Treatments; T1: control; T2: supplemented Se NPs 10 days; T3: supplemented Se NPs 20 days; T4: supplemented Se NPs 30 days. Different letters mean that treatments are significantly different at $(\mathrm{P}<0.05)$. Values are expressed as the mean $\pm \mathrm{SE}$.

\subsection{Serum protein and antioxidant enzymes changes}

Serum total protein (TP), albumin (ALB), globulin (GLO), and GLO fractions (Alpha, beta, and gamma) were only and significantly improved $(\mathrm{P}<0.05)$ in $\mathrm{T} 4$ in which fish fed on Se NPs supplementation for 30 days (Table 2). The control (T1) treatment differed insignificantly from $(\mathrm{P}<0.05)$ treatments fed on a diet supplemented with $\mathrm{Se}$ NPs for 10 or 20 days.

Table 2: Total protein and globulin fractions in C. carpio blood.

\begin{tabular}{|l|l|l|l|l|}
\hline Item & T1 (Control) & T2 (10 day) & T3 (20 day) & T4 (30 day) \\
\hline TP $(\mathrm{g} / \mathrm{dl})$ & & & & \\
\hline ALB $(\mathrm{g} / \mathrm{dl})$ & $4.3^{\mathbf{B}} \pm 1.5$ & $4.72^{\mathbf{B}} \pm 0.06$ & $4.6^{\mathbf{B}} \pm 0.21$ & $5.83^{\mathbf{A}} \pm 0.27$ \\
\hline GLO $(\mathrm{g} / \mathrm{dl})$ & $2.17^{\mathbf{B}} \pm 0.03$ & $2.27^{\mathbf{B}} \pm 0.09$ & $2.16^{\mathbf{B}} \pm 0.07$ & $2.73^{\mathbf{A}} \pm 0.12$ \\
Alpha $(\mathrm{g} / \mathrm{dl})$ & $2.13^{\mathbf{B}} \pm 0.13$ & $2.45^{\mathbf{B}} \pm 0.05$ & $2.43^{\mathbf{B}} \pm 0.14$ & $3.1^{\mathbf{A}} \pm 0.17$ \\
Beta $(\mathrm{g} / \mathrm{dl})$ & $0.55^{\mathbf{B}} \pm 0.03$ & $0.61^{\mathbf{B}} \pm 0.01$ & $0.67^{\mathbf{B}} \pm 0.08$ & $0.95^{\mathbf{A}} \pm 0.04$ \\
Gamma $(\mathrm{g} / \mathrm{dl})$ & $0.47^{\mathbf{B}} \pm 0.07$ & $0.53^{\mathbf{A B}} \pm 0.02$ & $0.48^{\mathbf{B}} \pm 0.06$ & $0.69^{\mathbf{A}} \pm 0.05$ \\
& $1.12^{\mathbf{B}} \pm 0.04$ & $1.3^{\mathbf{A}} \pm 0.09$ & $1.29^{\mathbf{A}} \pm 0.1$ & $1.47^{\mathbf{A}} \pm 0.09$ \\
\hline
\end{tabular}


Treatments; T1: control; T2: supplemented Se NPs 10 days; T3: supplemented Se NPs 20 days; T4: supplemented Se NPs 30 days. TP: total protein; ALB: albumin; GLO: globulin. Values are presented as the mean \pm SE. Treatments with different letters within the same row are significantly different at $\mathrm{P} \leq .05$.

In Fig. (2), the antioxidant enzymes GPx, CAT, and SOD activity in the hepatic tissues of the experimental fish were significantly and gradually increased with the supplementation period of Se NPs, C. carpio. T4, fed on supplementation for 30 days, had a significantly higher antioxidant activity compared to the control fish.

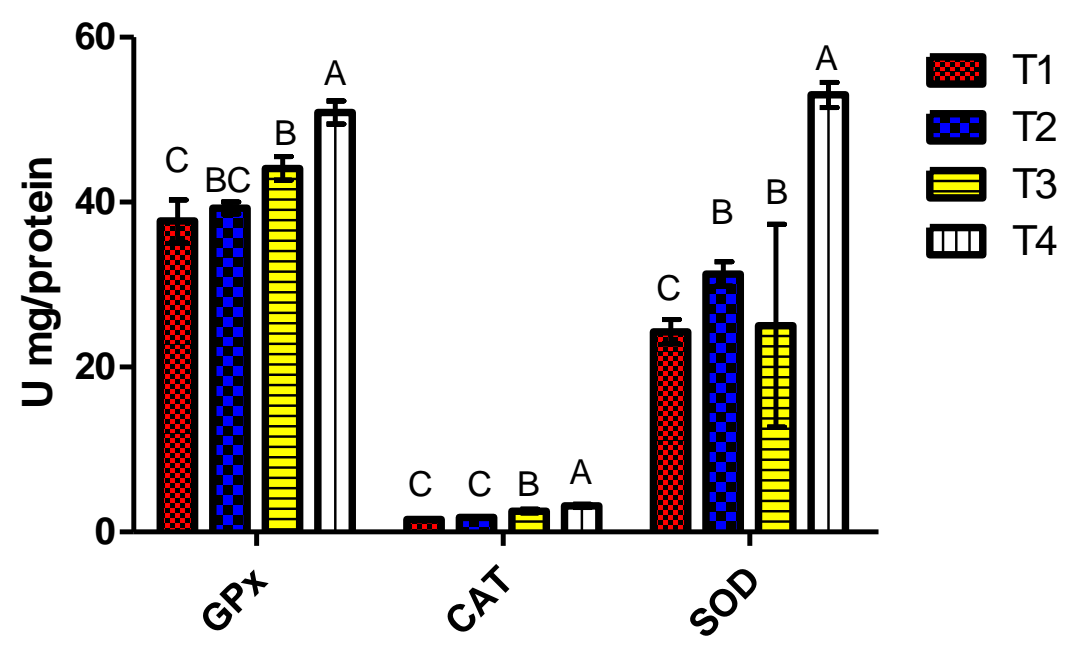

Fig. 2: Antioxidant activities in the liver tissues of C. carpio.

( $n=3 /$ replicate) GPx: Glutathione peroxidase enzyme; CAT: catalase enzyme; SOD: Superoxide dismutase enzyme. Treatments; T1: control; T2: supplemented Se NPs 10 days; T3: supplemented Se NPs 20 days; T4: supplemented Se NPs 30 days. Different letters mean that treatments are significantly different at $(\mathrm{P}<$ $0.05)$. Values are presented as the mean $\pm \mathrm{SE}$.

\subsection{Genotoxicity of $C$. carpio fed on Se NPs supplementation}

Determination of the DNA damage in fish liver is summarized in Table (3) and Figs. $(3,4,5)$. The results found that control liver and nano-Se liver tissues, treated groups at several time intervals $(10,20$, and 30 days), were significantly decreased $(\mathrm{P}<$ 0.05) in DNA damage values compared to the positive control as exposed to bacterial infection. However, the DNA damage rates were significantly increased in the liver of fish treated with bacteria. On the contrary, the DNA damage rates were decreased significantly in the liver tissues exposed to bacterial infection and treated with Se NPs at different time intervals in which the 30 days treatment (T4) was the most effective time.

Determination of the DNA fragmentation rates in the fish liver is summarized in Table (4) and Figs. (3, 4). Results revealed that the DNA fragmentation rates were significantly increased $(\mathrm{P}<0.001)$ in liver of fish treated exaction with bacteria. On the contrary, the DNA fragmentation rates were significantly decreased in liver tissues 
exposed to bacterial infection and treated with Se NPs at different time intervals in which the 30 days treatment was the most effective time.

The results of micronuclei in blood cells of C.carpio of different treatments are summarized in Table (5). According to the results, the micronuclei frequency in fishes treated with nano selenium at different times didn't show any significant difference comparing to the control except at day 30 which slightly increased more than the control. In fishes exposed to bacterial infection, the micronuclei frequency increased significantly compared to the control $(\mathrm{P} \leq 0.05)$. On the contrary, all treatments exposed to bacterial infection and treated with Se NPs at different time intervals (10, 20, and 30 days) were significantly decreased $(\mathrm{P}<0.05)$ in micronuclei frequency values compared to the positive control exposed to bacterial infection in which the 30 days treatment was the most effective time.

Table 3: Visual score of DNA damage in hepatic tissues of $C$. carpio supplemented with Se NPs and/ or bacterial infection.

\begin{tabular}{|c|c|c|c|c|c|c|c|}
\hline \multirow{2}{*}{ Treatment } & \multicolumn{2}{|c|}{ No. of cells } & \multicolumn{4}{|c|}{ Class $^{* * *}$} & \multirow{2}{*}{$\begin{array}{c}\text { DNA damaged cells \% } \\
(\text { Mean } \pm \text { SEM })\end{array}$} \\
\hline & Analyzed $^{*}$ & Comets & $\mathbf{0}$ & 1 & 2 & 3 & \\
\hline \multicolumn{8}{|c|}{ Un infected fish } \\
\hline T1 & 400 & 30 & 370 & 27 & 3 & 0 & $7.52 \pm 0.65^{\mathrm{d}}$ \\
\hline $\mathbf{T 2}$ & 400 & 31 & 369 & 25 & 4 & 2 & $7.75 \pm 0.86^{\mathrm{d}}$ \\
\hline T3 & 400 & 35 & 365 & 24 & 7 & 4 & $8.76 \pm 1.25^{\mathrm{cd}}$ \\
\hline T4 & 400 & 37 & 363 & 22 & 9 & 6 & $9.27 \pm 1.11^{\mathrm{c}}$ \\
\hline \multicolumn{8}{|c|}{ Infected fish } \\
\hline T1 & 400 & 98 & 302 & 31 & 28 & 39 & $24.50 \pm 1.19^{\mathrm{a}}$ \\
\hline $\mathbf{T} 2$ & 400 & 69 & 331 & 28 & 25 & 16 & $17.25 \pm 1.13^{b}$ \\
\hline T3 & 400 & 58 & 342 & 21 & 24 & 13 & $14.50 \pm 1.04^{\mathrm{bc}}$ \\
\hline T4 & 400 & 41 & 359 & 17 & 14 & 10 & $10.25 \pm 1.12^{\mathrm{c}}$ \\
\hline
\end{tabular}

$*$ : Number of cells examined per a group, $* *$ : Class $0=$ no tail; $1=$ tail length $<$ diameter of nucleus; $2=$ tail length between $1 \mathrm{X}$ and $2 \mathrm{X}$ the diameter of nucleus; and $3=$ tail length $>2 \mathrm{X}$ the diameter of nucleus. Treatments; T1: control; T2: supplemented Se NPs 10 days; T3: supplemented Se NPs 20 days; T4: supplemented Se NPs 30 days. Values are presented as the mean \pm SE. Treatments with different letters within the same row are significantly different at $\mathrm{P} \leq .05$. 
Table 4: DNA fragmentation detected in hepatic tissues of $C$. carpio supplemented with Se NPs and/ or bacterial infection.

\begin{tabular}{|l|c|c|c|}
\hline Treatment & DNA Fragmentation \% & Change & Inhibition \\
\hline \multicolumn{4}{|c|}{ Un infected fish } \\
\hline T1 & $8.2 \pm 0.25^{\mathrm{d}}$ & 0 & 0 \\
\hline T2 & $8.1 \pm 0.32^{\mathrm{d}}$ & 0.1 & 100.49 \\
\hline T3 & $9.3 \pm 0.56^{\mathrm{d}}$ & 1.1 & 94.61 \\
\hline T4 & $10.2 \pm 0.63^{\text {cd }}$ & 2 & 90.20 \\
\hline \multicolumn{5}{|c|}{ Infected fish $^{-1}$} \\
\hline T1 & $28.6 \pm 0.82^{\mathrm{a}}$ & 20.4 & 0.00 \\
\hline T2 & $21.5 \pm 0.48^{\mathrm{b}}$ & 13.3 & 34.80 \\
\hline T3 & $17.9 \pm 0.67^{\text {bc }}$ & 9.7 & 52.45 \\
\hline T4 & $12.4 \pm 0.35^{\mathrm{c}}$ & 4.2 & 79.41 \\
\hline
\end{tabular}

Treatments; T1: control; T2: fed Se NPs 10 days; T3: fed Se NPs 20 days; T4: fed Se NPs 30 days. Values are presented as the mean \pm SE.Means with different superscripts ( $a$ and $b$ ) between locations in the same column are significantly different at $\mathrm{P}<0.05$.

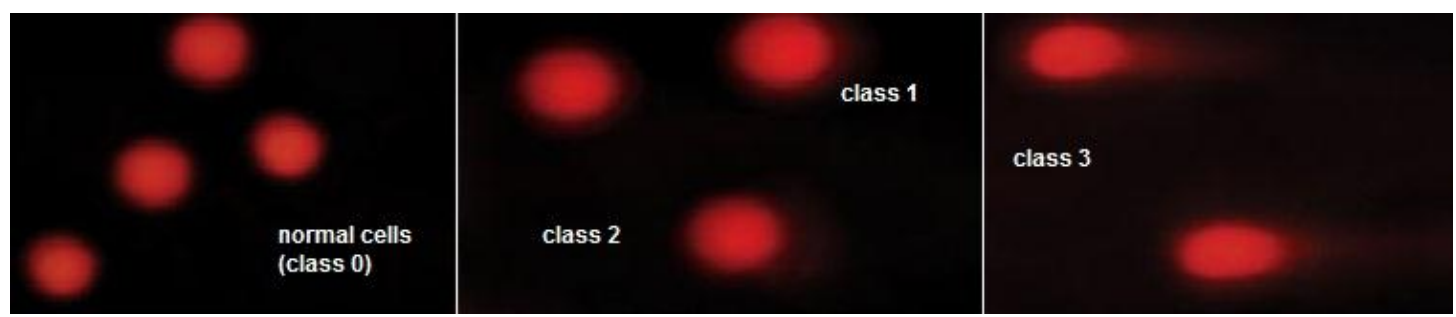

Fig. 3: Visual score using comet assay of normal DNA (class 0) and DNA damage (classes 1, 2 and 3) in hepatic tissues of fish supplemented with Se NPs and/ or bacterial infection. 
Table 5: Micronuclei frequencies (\%) in blood erythrocytes of $C$. carpio supplemented with Se NPs and/or bacterial infection.

\begin{tabular}{|c|c|c|}
\hline Treatment & Total number of counted cells/group & MN frequency $(\%)$ \\
\hline \multicolumn{3}{|c|}{ Un infected fish } \\
\hline T1 & 10000 & $0.09 \pm 0.02^{f}$ \\
\hline $\mathbf{T 2}$ & 10000 & $0.11 \pm 0.02^{f}$ \\
\hline T3 & 10000 & $0.14 \pm 0.03^{\text {ef }}$ \\
\hline $\mathbf{T 4}$ & 10000 & $0.20 \pm 0.02 \mathrm{de}$ \\
\hline \multicolumn{3}{|c|}{ Infected fish } \\
\hline T1 & 10000 & $0.71 \pm 0.02^{\mathrm{a}}$ \\
\hline $\mathbf{T 2}$ & 10000 & $0.57 \pm 0.03^{\mathrm{b}}$ \\
\hline $\mathbf{T 3}$ & 10000 & $0.38 \pm 0.01^{\mathrm{c}}$ \\
\hline $\mathbf{T 4}$ & 10000 & $0.23 \pm 0.01^{\mathrm{d}}$ \\
\hline
\end{tabular}

Treatments; T1: control; T2: supplemented Se NPs 10 days; T3: supplemented Se NPs 20 days; T4: supplemented Se NPs 30 days. Treatments with different letters within the same row are significantly different at $\mathrm{P} \leq .05$. Values are presented as the mean $\pm \mathrm{SE}$.

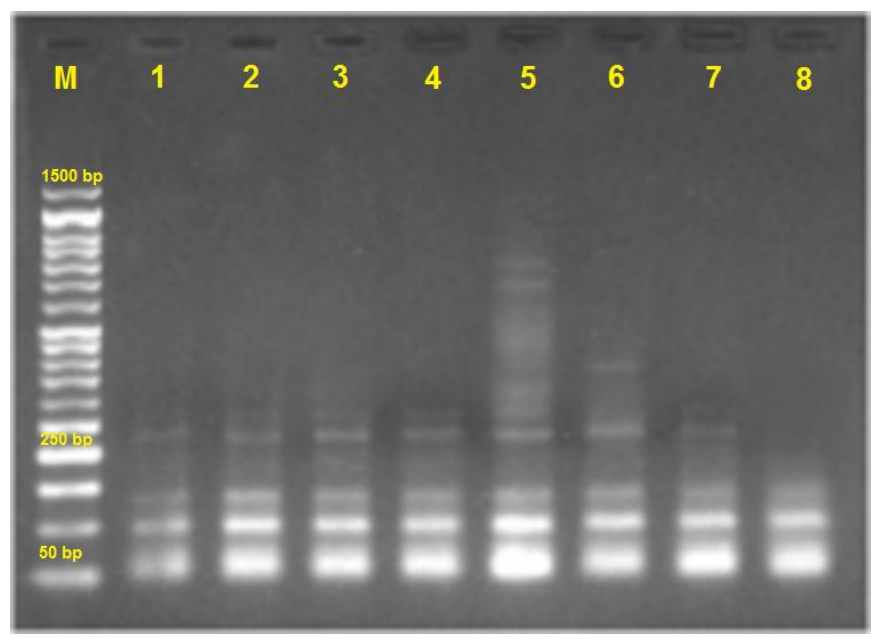

Fig. 4: DNA fragmentation detected with Agarose gel in hepatic tissues of $C$. carpio treated with Se NPs and/ or bacterial infection.

M: represent DNA marker, Lanes 1: Control treatment (-ve), Lane 2: represents fish supplemented with Se NPs 10 days, Lane 3: represents fish supplemented with Se NPs 20 days, Lane 4: represents fish supplemented with Se NPs 30 days, Lane 5: represents fish exposed to bacterial infection, Lanes 6-7: represent fish similar to those in lanes 2-4 plus bacterial infection. 


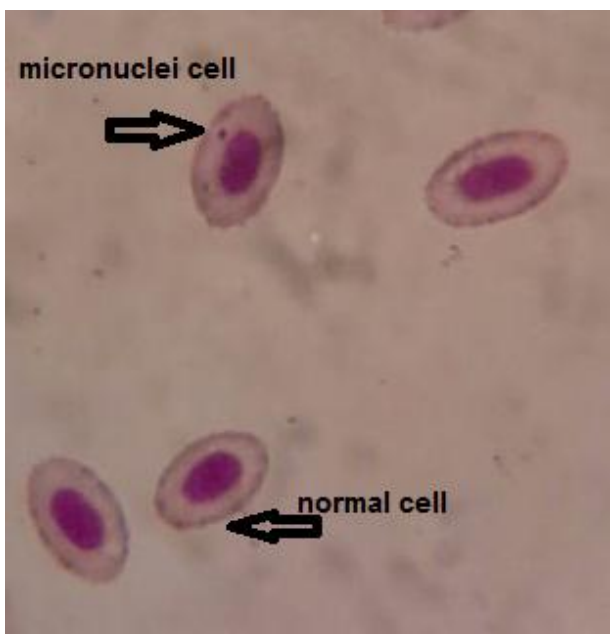

Fig. 5: Erythrocytes of $C$. carpio showing micronucleus induced by bacterial infection.

\section{Histopathological analyses of $\boldsymbol{C}$. carpio fed on Se NPs supplementation}

Three tissues liver, kidney, and spleen were histopathologically examined for any alterations accompanied by the Se NPs supplementation and A. hydrophila infection. Hepatic tissue of $C$. carpio showed no alteration after feeding Se NPs for different periods 10, 20, and 30 days.

Hepatic tissue of $C$. carpio challenged with A. hydrophila showed necrotic areas (Fig. 6a), these lesions were decreased in C. carpio supplemented with Se NPs in timedependent manners as T4 (Fig. 6c) was less pronounced than T2 (Fig. 6b). Renal tissue of challenged $C$. carpio (Fig. 7a) was heavily infiltrated with inflammatory cells and Se NPs supplementation for 30 days T4 (Fig. 7c) had the same change; while C. carpio supplemented with Se NPs for 10 days T2 (Fig. 7b) had a significant reduction in cellular infiltrations compared to the control treatment. Melano-macrophages centre was markedly proliferated in spleen tissues of challenged fish (Fig. 8a) and supplemented with Se NPs (Figs. 8b,8c). 

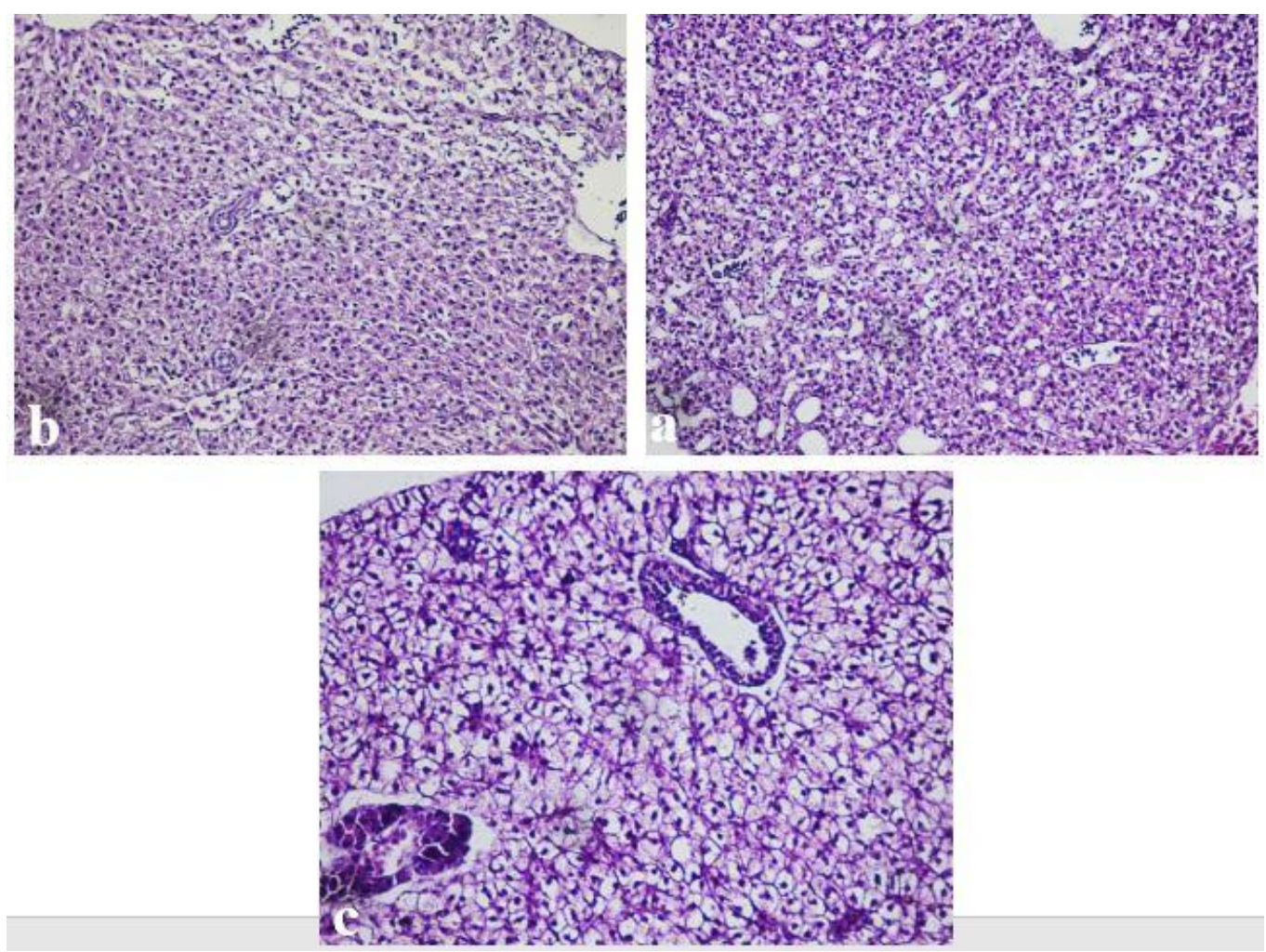

Fig. 6: Hepatic tissue with marked degeneration in A. hydrophila (T1) (a), with gradual reduction in the degeneration severity in Se NPs treated (T2) (b), and mild degree of degeneration in Se NPs supplemented (T4) (c). H\&E X 400. 


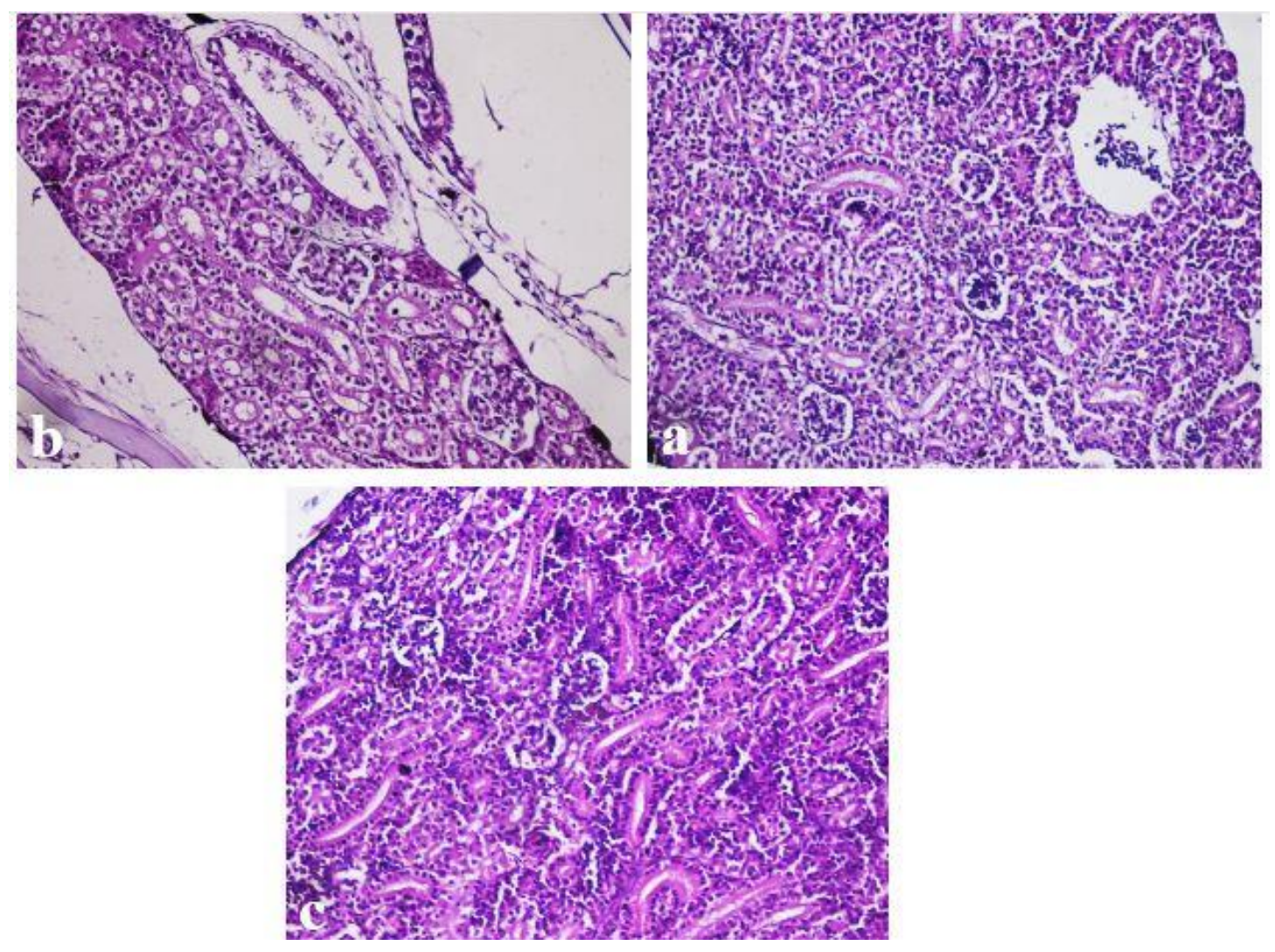

Fig. 7: Renal tissue with heavy interstitial inflammatory cells infiltration associated with glomerular degeneration in A. hydrophila (T1) (a). Absence of inflammatory cells infiltration in Se NPs supplemented (T2) (b), while massive inflammatory cells infiltration in Se NPs supplemented (T4) (c). H\&E X 400 


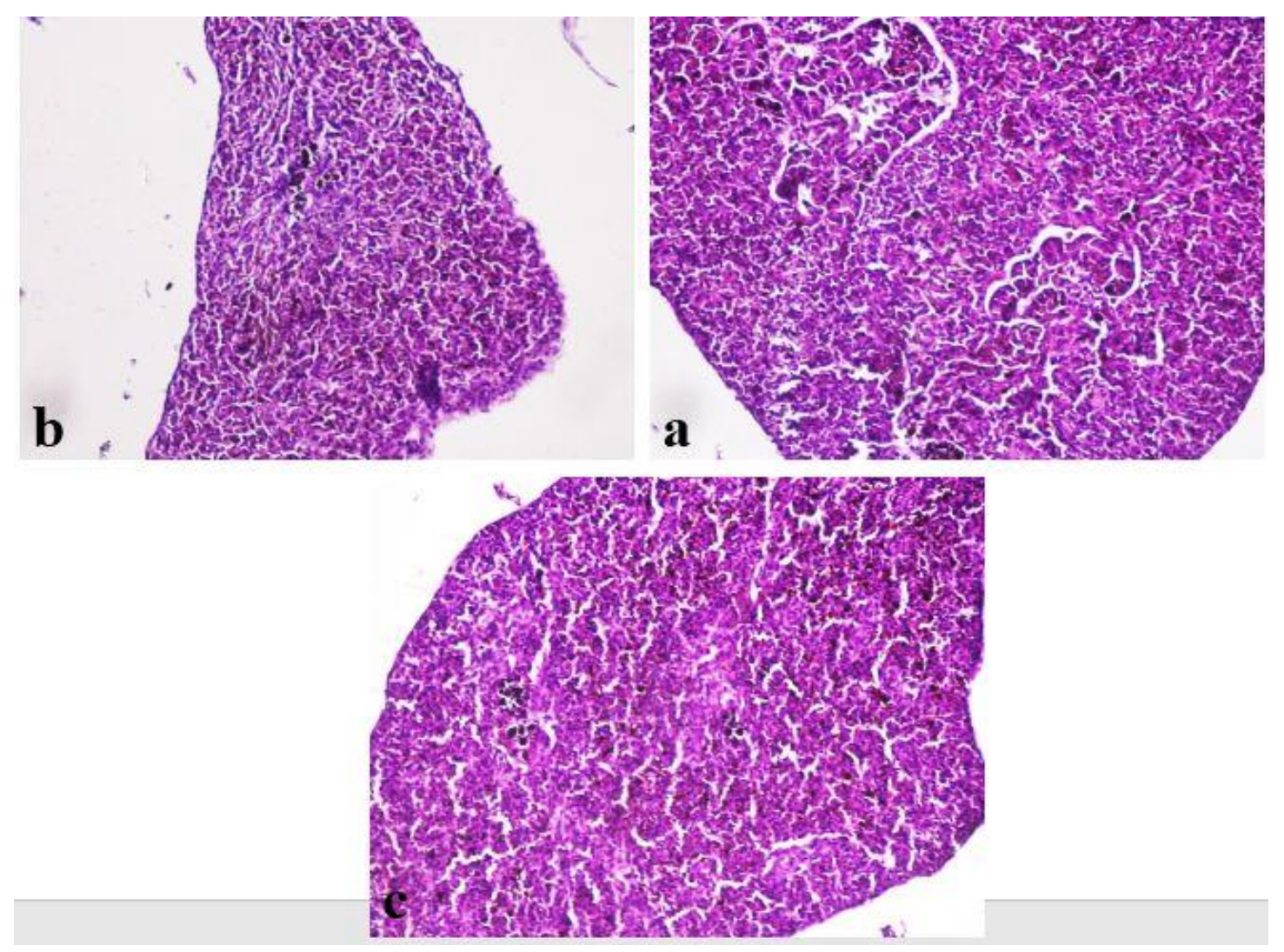

Fig. 8: Spleen with marked activation of melanomacrophages in A. hydrophila (T1) (a), Se NPs supplemented (T2) (b), and Se NPs supplemented (T4) (c) groups. H\&E X 400

\section{DISCUSSION}

In the last decade, many researchers (Abdel-Tawwab et al., 2018; Nikapitiya $\boldsymbol{e t}$ al., 2018; Sherif et al., 2019) stated that nano-materials became widely used in fish production for their positive properties (immunostimulant and diseases resistant) and also, less toxic compared with their organic and/or inorganic sources.

The pilot challenge with pathogenic agents is the most reliable test for judging the immune system (Köllner et al., 2002). In a time-dependent manner, C. carpio fed on Se NPs supplemented diet $(1 \mathrm{mg} / \mathrm{kg}$ feed) had a lower mortality rate than the control treatment, fish fed on Se NPs supplementation had improved disease resistance against the experimental challenge with A. hydrophila, particularly with those in T4 (fed on Se NPs for 30 days) which had 13 out 50 survival rate. Similarly, Jobling (2012) observed that in many fish species a dose of 0.15 to $0.7 \mathrm{mg} / \mathrm{kg}$ of nano-selenium meets the optimum requirement needed for the normal growth performance without any nutritional disorders. Supporting our findings, $C$. carpio feeding a diet supplemented with $\beta-1,3$ glucan binding protein-based selenium nanowire $(0.5 \mathrm{mg}, 1 \mathrm{mg}$, and $2 \mathrm{mg}$ for 30 days) could resist aquatic pathogen infection; namely, A. hydrophila, Vibrio parahaemolyticus and V. alginolyticus, and showed a high surviving rate (Iswarya et al., 2018). 
Furthermore, with the same dose, Kumar et al. (2018) stated that Pangasinodon hypophthalmus could resist the experimental infection with A. veronii biovar sobria showing a low cumulative mortality rate. Furthermore, the immune stimulant, antioxidant, bioavailability, and low toxicity properties of Se NPs $(0.7 \mathrm{mg} / \mathrm{kg})$ could counteract the bacterial challenge in $O$. niloticus (Neamat-Allah et al., 2019) and $C$. carpio (Saffari et al., 2018).

In this study, A. hydrophila could not be isolated from challenged C. carpio at the third week after experimental infection in T4 (fed on Se NPs $1 \mathrm{mg} / \mathrm{kg}$ feed for 30 days). In accordance, Neamat-Allah et al. (2019) stated that the mortality of $O$. niloticus which was challenged with S. iniae ceased at 5th, 12th, and 14th days in, Se NPs, Se, and control, respectively, with mortality rates of $93.33 \%, 73.33 \%$, and $26.66 \%$, respectively. This indicates that Se NPs speed the recovery and elimination of pathogenic agents.

The anti-inflammatory cytokine IL-10 was significantly increased $(\mathrm{P}<0.05)$ in $C$. carpio fed on Se NPs whereas, pro-inflammatory cytokines TNF- $\alpha$, IL- $1 \beta$, and IL-8 were significantly lowered with time compared to the control treatment. In accordance, the pro-inflammatory cytokines, IL- 8 , TNF- $\alpha$, and transforming growth factor- $\beta$ were significantly $(\mathrm{P}<0.05)$ decreased at $0.67-1.46 \mathrm{mg} / \mathrm{kg}$; whereas, IL-10 was down-regulated with lower supplementation doses $<0.67 \mathrm{mg} / \mathrm{kg}$ (Jingyuan et al., 2020). In the same way, IL-10 was decreased in zebrafish and chinook salmon (Oncorhynchus tshawytscha) that received lower selenium supplementation diets (Lulijwa et al., 2019; Wang et al., 2020). In contrast, the anti-inflammatory cytokine in fish is up-regulated in response to inflammation and adverse conditions (Saber et al., 2019; Jiang et al., 2020), these observations are not in contrast with the present findings, since Se NPs enhanced the immune responses (anti-inflammatory cytokines) and it did not initiate an inflammation (low pro-inflammatory cytokines).

The resistance of fish against bacterial infections relies on their immune status. Therefore, biochemical parameters in plasma (Davis 2004, Sherif et al., 2021b), total protein, and albumin (Ortuno et al., 2001) are good tools to assess the immunity of fish. The current findings testified that the TP, ALB, GLO, and GLO fractions (Alpha, beta, and gamma) were improved in T4 (fed Se NPs supplementation $1 \mathrm{mg} / \mathrm{kg}$ feed for 30 days) while, no changes was recorded in T2 or T3 (fed on Se NPs for 10 and 20 days, respectively). Fish fed on Se had improvements in the serum levels of total protein, globulin, and albumin since Se is a part of selenoprotein that helps in albumin syntheses (Suzuki et al., 2010; Ashouri et al., 2015; Mansour et al., 2017), total protein and albumin in plasma also improved with Se NPs additions (Jingyuan et al., 2020). Nevertheless, the decrease in the serum protein contents was observed in fish infected with S. iniae due to immunosuppression and/or hepatic dysfunction (Badr et al., 2012).

Study findings showed an enhancement in a time-dependent manner in the antioxidant activity (CAT, GPx, and SOD) of liver of C. carpio fed on Se NPs (1 mg/kg feed). In agreement, the activities and gene expression of hepatic antioxidant enzymes 
(GPx, CAT, and SOD), as well as reduced glutathione (GSH) level, were enhanced at a dose of Se 1.06 ( $\mathrm{P}<0.05$ ) (Kumar et al., 2018; Jingyuan et al., 2020). Noticeably, the $\mathrm{Se}$ is an active component of glutathione peroxidase enzymes that eliminates the adverse impacts of ROS with the (Reeves \& Hoffmann, 2009); while, Se NPs had higher activities of antioxidant enzymes (GPx, NO, SOD, and CAT) than other Se forms organic or inorganic in the experimental fish (Sarkar et al., 2015; Saffari et al., 2018).

When the antioxidant capacity fails to neutralize the accumulated ROS in cells, oxidative stress emerges, resulting in DNA damages, including base pairs aberrations in (He et al., 2018; Kassotis et al., 2018). The content of the antioxidant enzymes is an important indicator for the health of fish and the integrity of their body tissues and cells. Cytogenetic analysis of chromosomes can be used to assess the biological effects of any genotoxic substance on fish (Frenzilli et al., 2009). Our findings concerning the activity of antioxidant enzymes indicated that Se NPs protect the fish cells from genotoxicity, since comet assay, DNA fragmentation rates, and the presence of micronuclei in blood cells decreased significantly $(\mathrm{P}<0.05)$ in fish received Se NPs $(1 \mathrm{mg} / \mathrm{kg}$ feed $)$ mainly in T4 (30 days treatment was the most effective period). Antioxidant enzymes GPx, CAT, and SOD catalyse the conversion of hydrogen peroxide and fatty acid hydro-peroxides into the water and fatty acid alcohol protecting cell membranes against oxidative damage (Watanabe et al., 1997), and protecting the cell membranes, DNA, proteins, and lipids against oxidative stress (Hodgson et al., 2006). It is worth noting that, using Se NPs is safe (low toxicity) and more bioavailable than the other forms of Se (organic and inorganic) (Wang et al., 2007).

In Fig. (6a), a bacterial infection in C. carpio resulted in severe degeneration and areas of necrosis even for the complete absence of hepatocytes, bacterial toxins caused upregulation of $\mathrm{NO}$ and TNF- $\alpha$ expression. Those reactions stimulate inflammatory responses with further hepatic damages (Shimohashi et al., 2000) and necrosis (Shobana et al., 2018). In accordance, Chopra et al. (2000) stated that cytotoxic enterotoxin of $A$. hydrophila upregulated pro-inflammatory TNF- $\alpha$ and (Cox 2 and Bcl-2). Those cytokines mediate tissue degeneration and necrosis (Song et al., 2014). In the present results, the enhancements in histopathological features in C. carpio supplemented with Se NPs (Figs. $6 \mathrm{~b}, 6 \mathrm{c})$ could be attributed to immunological and antioxidant properties of Se. Similarly, Se transfers into selenoproteins and stimulates the anti-inflammatory and anti-apoptotic effect with down regulation of TNF- $\alpha$ with further down-regulation of cyclooxygenase (Cox2) and B-cell lymphoma (Bcl2) (Huang et al., 2012; Qian et al., 2019; Fan et al., 2020). In addition, Avery and Hoffmann (2018) denoted that the Se deficiency is accompanied with up-regulating some inflammatory responses.

In Fig. (7a), the fish kidney was infiltrated with inflammatory cells after $A$. hydrophila infection, which is explained by the findings of Majumdar et al. (2007) who stated that $A$. hydrophila enhances macrophages which are the first line of defense against 
the microbial challenge. In the present results, fish supplemented with Se NPs (T2) for 10 days (Fig. 7b) had low cellular infiltration in kidney tissue compared with those supplemented for longer periods (30 days) in T4 (Fig. 7c). Nano-particles affect and modulate the neutrophil's functions in a time-dependent and concentration manner (Collins \& Meyer 2009; Griffitt et al., 2009; Combs et al., 2011). Different findings were reported by Jovanovic et al. (2011) who mentioned that high levels of nanoparticle accumulation in tissues resulted in a reduction of inflammatory cell infiltration and subsequently immune response against bacterial infection. In agreement, do Carmo et al. (2018) and Shobana et al. (2018) observed degeneration and necrosis in renal tubule and glomeruli with hypotrophy.

As shown in Fig. (8a), a marked proliferation of melano-macrophages in the spleen of $C$. carpio was experimentally infected with A. hydrophila. Spleen tissue formed of melanomacrophage centres which are an aggregation of highly pigmented macrophages playing an immunological role (Kipp et al., 2009). Changes in the number, size, and cellular content occurred in response to microbial challenge (Daeron, 1997). Similar changes in the spleen (marked proliferation of melano-macrophages) were observed in $C$. carpio fed on a diet supplemented with Se NPs for 10 days (Fig. 8b) and 30 days (Fig. $8 c)$. Those histopathological alterations were due to the accumulation of Se NPs in the spleen which is one of the prediction sites of bioaccumulation (Gutscher et al., 2009).

\section{CONCLUSION}

Feeding on a diet supplemented with selenium (nano-size) improves the immune and antioxidative status of $C$. carpio. Serum total protein, globulin, levels of antiinflammatory (IL-10), as well as antioxidant enzymes (GPx, CAT, and SOD) in serum were gradually and significantly enhanced with fish fed on Se NPs (1 mg / kg fish feed). Due to those improvements, $C$. carpio could resist bacterial infection as no bacteria were isolated from fish fed for 30 days on supplementation at the third week after experimental infection. C. carpio, fed Se NPs for 30 days, showed lower histopathological lesions, DNA damages, and micronuclei even after bacterial infection. Thus, it could be safe to feed common carp (C. carp) with Se NPs without any threat to fish health.

\section{Acknowledgment}

This work was financially supported in the framework of the project "Biological production of nano-selenium spheres and its application in livestock production" by the National Strategy for Genetic Engineering and Biotechnology, Academy of Scientific Research and Technology, Egypt.

\section{REFERENCES}

Abdel-Tawwab, M.; Samir, F.; Abd El-Naby, A.S. and Monier, M.N. (2018). Antioxidative and immunostimulatory effect of dietary cinnamon nanoparticles on 
the performance of Nile tilapia, Oreochromis niloticus (L.) and its susceptibility to hypoxia stress and Aeromonas hydrophila infection. Fish Shellfish Immunol., 74: 19-25. https://doi.org/10.1016/j.fsi.2017.12.033

Abutbul, S.; Golan-Goldhirsh, A.; Barazani, O. and Zilberg, D. (2004). Use of Rosmarinus officinalis as a treatment against Streptococcus iniae in tilapia (Oreochromis sp.). Aquaculture., 238(1-4): 97-105. $\quad$ https://doi.org/10.1016/ j.aquaculture. 2004.05.016

Al-Sabti, K. and Metcalfe, C. D. (1995). Fish micronuclei for assessing genotoxicity in water. Mutat Res Genet Toxicol., 343(2-3): 121-135. https://doi.org/10.1016/01651218(95)90078-0

Anderson, M. E. and Greenwald, R. (1985). Handbook of methods for oxygen radical research. Florida: CRC Press Inc, 317-23.

Ashouri, S.; Keyvanshokooh, S.; Salati, A.P. ; Johari, S. A. and Pasha-Zanoosi, H. (2015). Effects of different levels of dietary selenium nanoparticles on growth performance, muscle composition, blood biochemical profiles and antioxidant status of common carp (Cyprinus carpio). Aquaculture., 446: 25-29. https://doi.org/10.1016/j.aquaculture.2015.04.021

Austin, B. and Austin, D. A. (2012). Bacterial fish pathogens: Disease of farmed and wild fish, 3rd edition. 112-115.

Avery, J.C. and Hoffmann, P.R. (2018). Selenium, selenoproteins, and immunity. Nutrients., 10(9): 1203. https://doi.org/10.3390/nu10091203

Badr, M.O.; Hashem, M.A. and Elmandrawi, S.A. (2012). Clinicopathological studies on some antibiotics used in Nile tilapia infected with Streptoccocus iniae. Am. J. Sci., 8(12): 1057-1070.

Bergey, D.H. (1994). Bergey's Manual of Determinative Bacteriology, ed. R. E. Buchaman \& N. E. Gibbons, 9lh ed. Baltimore: Williams and Wilkins.

Beutler, E. (1984). Superoxide dismutase. In: Beutler, E. (Ed.), Red Cell Metabolism. A Manual of Biochemical Methods. Grune \& Stratton, Philadelphia, PA, pp. 83-85.

Biller-Takahashi, J.D.; Takahashi, L.S.; Mingatto, F.E. and Urbinati, E.C. (2015). The immune system is limited by oxidative stress: dietary selenium promotes optimal antioxidative status and greatest immune defense in pacu Piaractus mesopotamicus. Fish $\quad$ Shellfish Immunol., 47(1): 360-367. https://doi.org/10.1016/j.fsi.2015.09.022

Bio-merieux (1984). Laboratory reagents and products. Bacterial. Barcy-L. Etiole 69260 charbonmieres-Les- Bams. France.

Blasiak, J.; Arabski, M.; Krupa, R.; Wozniak, K.; Zadrozny, M.; Kasznicki, J.; Zurawska, M. and Drzewoski, J. (2004). DNA damage and repair in type 2 diabetes mellitus. MUTAT RES-FUND MOL M., 554(1-2): 297-304. https://doi.org/10.1016/j.mrfmmm.2004.05.011 
Chopra, A.K.; Xu, X.J.; Ribardo, D.; Gonzalez, M.; Kuhl, K.; Peterson, J.W. and Houston, C.W. (2000). The cytotoxic enterotoxin of Aeromonas hydrophila induces proinflammatory cytokine production and activates arachidonic acid metabolism in macrophages. Infect. Immun., 68(5): 2808-2818. DOI: 10.1128 /IAI.68.5.2808-2818.2000

Collins, A.; Dušinská, M.; Franklin, M.; Somorovská, M.; Petrovská, H.; Duthie, S.; Fillion, L.; Panayiotidis, M.; Raslova, K. and Vaughan, N. (1997). Comet assay in human biomonitoring studies: reliability, validation, and applications. Environ. Mol.Mutagen., 30(2): $\quad$ 139-146. $\quad$ https://doi.org/10.1002/(SICI)10982280(1997)30:2<139::AID-EM6>3.0.CO;2-I

Collins, S.R. and Meyer, T. (2009). Calcium flickers lighting the way in chemotaxis?. Dev. Cell., 16(2): 160-161. https://doi.org/10.1016/j.devcel.2009.01.018

Combs, G.F.; Watts, J.C.; Jackson, M.I.; Johnson, L.K.; Zeng, H.; Scheett, A.J.; Uthus, E.O.; Schomburg, L.; Hoeg, A.; Hoefig, C.S.; Davis, C.D. and Milner, J. A. (2011). Determinants of selenium status in healthy adults. Nutr. J., 10(1), 1-10. https://doi.org/10.1186/1475-2891-10-75

Daeron, M. (1997). Fc receptor biology. Annu. Rev. Immunol., 15(1), 203-234.

Davis, K.B. (2004). Temperature affects physiological stress responses to acute confinement in sunshine bass (Morone chrysops $\times$ Morone saxatilis). Comp. Biochem. Physiol. Part A Mol. Integr. Physiol., 139(4), 433-440. https://doi.org/10.1016/j.cbpb.2004.09.012

de Andrade, V.M.; de Freitas, T.R. and da Silva, J. (2004). Comet assay using mullet (Mugil sp.) and sea catfish (Netuma sp.) erythrocytes for the detection of genotoxic pollutants in aquatic environment. Mutat Res Genet Toxicol Environ Mutagen., 560(1): 57-67. https://doi.org/10.1016/j.mrgentox.2004.02.006

do Carmo, T.L.L.; Azevedo, V.C.; de Siqueira, P.R.; Galvão, T.D.; Dos Santos, F. A.; dos Reis Martinez, C.B.; Appoloni, C.R. and Fernandes, M. N. (2018). Reactive oxygen species and other biochemical and morphological biomarkers in the gills and kidneys of the Neotropical freshwater fish, Prochilodus lineatus, exposed to titanium dioxide $\left(\mathrm{TiO}_{2}\right)$ nanoparticles. Environ. Sci. Pollut. Res., 25(23): 22963-22976. https://doi.org/10.1007/s11356-018-2393-4

Doumas, B.T.; Waston, W.A. and Biggs, H.G. (1971). Albumin standards and the measurements of serum albumin with Bromocresol Green. Clinica Chimica Acta, 31: 87-96.

Duncan, D.B. (1955). Multiple range and multiple "F" test. Biometrics 11, 10.

Elmer, W.K.; Stephen, D.A.; William, M.J.; Paul, C.S. and Washington, C.W. (1997). A Color Atlas and Text Book of Diagnostic Microbiology. 5th Ed. Lippincott. Philadelphia. New York. 
Eszenyi, P.; Sztrik, A.; Babka, B. and Prokisch, J. (2011). Production of Lactomicrosel® and nanosize (100-500 NM) selenium spheres by probiotic lactic acid bacteria. In International Conference on Food Engineering and Biotechnology IPCBEE., 9: 858-862.

Fan, R.F.; Liu, J.X.; Yan, Y. X.; Wang, L. and Wang, Z. Y. (2020). Selenium relieves oxidative stress, inflammation, and apoptosis within spleen of chicken exposed to mercuric chloride. Poult. Sci. J., 99(11): 5430-5439. https://doi.org/10.1016/j.psj.2020.08.031

FAO (Food and Agriculture Organization) (2018). Global Aquaculture Production Rome, Italy. http:// www.fao.org/fishery/statistics/global-aquacultureproduction/query/en.

Fontagné-Dicharry, S.; Godin, S.; Liu, H.; Prabhu, P.A.J.; Bouyssiere, B.; Bueno, M.; Tacon, P.; Médale, F. and Kaushik, S. J. (2015). Influence of the forms and levels of dietary selenium on antioxidant status and oxidative stress-related parameters in rainbow trout (Oncorhynchus mykiss) fry. Br. J. Nutr., 113(12): 1876-1887. doi:10.1017/S0007114515001300

Forootanfar, H.; Adeli-Sardou, M.; Nikkhoo, M.; Mehrabani, M.; Amir-Heidari, B.; Shahverdi, A.R. and Shakibaie, M. (2014). Antioxidant and cytotoxic effect of biologically synthesized selenium nanoparticles in comparison to selenium $\begin{array}{lllll}\text { dioxide. J } & \text { Trace } & \text { Elem } & \text { Med } & \text { Biol., 28(1): }\end{array}$ https://doi.org/10.1016/j.jtemb.2013.07.005

Frenzilli, G.I.A.D.A.; Nigro, M.A.R.C.O. and Lyons, B.P. (2009). The Comet assay for the evaluation of genotoxic impact in aquatic environments. Mutat Res Rev Mutat Res ., 681(1): 80-92. https://doi.org/10.1016/j.mrrev.2008.03.001

Glick, B. (1968). Serum protien electrophoresis pattern in acrylamide gel. Pattern from normal and bursa less birds. Poult. Sci. J., 47: 807-814.

Griffitt, R.J.; Hyndman, K.; Denslow, N.D. and Barber, D.S. (2009). Comparison of molecular and histological changes in zebrafish gills exposed to metallic nanoparticles. Toxicol. Sci., 107(2): 404-415. https://doi.org/10.1093/toxsci/kfn256

Gutscher, M.; Sobotta, M.C.; Wabnitz, G.H.; Ballikaya, S.; Meyer, A.J.; Samstag, Y. and Dick, T.P. (2009). Proximity-based protein thiol oxidation by H2O2scavenging peroxidases. J. Biol. Chem., 284(46): $31532-31540$. https://doi.org/10.1074/jbc.M109.059246

Halliwell, B. (2006). Oxidative stress and neurodegeneration: where are we now?. J. Neurochem., 97(6):1634-1658. https://doi.org/10.1111/j.1471-4159.2006.03907.x

He, Y.; Sun, C.; Zhang, Y.; Folkerts, E.J.; Martin, J.W. and Goss, G.G. (2018). Developmental toxicity of the organic fraction from hydraulic fracturing flowback and produced waters to early life stages of zebrafish (Danio rerio). Environ. Sci. Technol. , 52(6): 3820-3830. 
Hodgson, J.C.; Watkins, C.A. and Bayne, C.W. (2006). Contribution of respiratory burst activity to innate immune function and the effects of disease status and agent on chemiluminescence responses by ruminant phagocytes in vitro. Vet. Immunol. Immunopathol., 112(1-2): 12-23. https://doi.org/10.1016/j.vetimm.2006.03.008

Huang, Z.; Rose, A.H. and Hoffmann, P. R. (2012). The role of selenium in inflammation and immunity: from molecular mechanisms to therapeutic opportunities. Antioxid Redox Signal, 16(7): 705-743. https://doi.org/10.1089/ars.2011.4145

Iswarya, A.; Vaseeharan, B.; Anjugam, M.; Gobi, N.; Divya, M. and Faggio, C. (2018). $\beta-1,3$ glucan binding protein based selenium nanowire enhances the immune status of Cyprinus carpio and protection against Aeromonas hydrophila infection. Fish shellfish immunol., 83: 61-75. https://doi.org/10.1016/j.fsi.2018.08.057

Jiang, W.D.; Zheng, X.; Feng, L.; Wu, P.; Liu, Y.; Jiang, J.; Kuang, S.Y.; Tang, L. and Zhou, X. Q. (2020). The antioxidant status, apoptosis, intercellular integrity and immune function of grass carp (Ctenopharyngodon idella) head kidney and spleen fed different levels of pyridoxine. Aquac. Nutr., 26(3): 613-630. https://doi.org/10.1111/anu.13022

Jingyuan, H.; Yan, L.; Wenjing, P.; Wenqiang, J.; Bo, L.; Linghong, M.; Qunlang, Z.; Hualiang, L. and Xianping, G. (2020). Dietary selenium enhances the growth and anti-oxidant capacity of juvenile blunt snout bream (Megalobrama amblycephala). Fish Shellfish Immunol. 101: 115-125. https://doi.org/10.1016/j.fsi.2020.03.041

Jobling, M. (2012). National research council (NRC): nutrient requirements of fish and shrimp, Aquac int. 20(3): 601-602. https://doi.org/10.1007/s10499-011-9480-6

Jovanovic, B.; Anastasova, L.; Rowe, E.W.; Zhang, Y.; Clapp, A.R. and Palić, D. (2011). Effects of nanosized titanium dioxide on innate immune system of fathead minnow (Pimephales promelas Rafinesque, 1820). Ecotoxicol. Environ. Saf. , 74(4): 675-683. https://doi.org/10.1016/j.ecoenv.2010.10.017

Kassotis, C.D.; Nagel, S.C. and Stapleton, H. M. (2018). Unconventional oil and gas chemicals and wastewater-impacted water samples promote adipogenesis via PPAR $\gamma$-dependent and independent mechanisms in 3T3-L1 cells. Sci. Total Environ., 640: 1601-1610. https://doi.org/10.1016/j.scitotenv.2018.05.030

Kipp, A.; Banning, A.; van Schothorst, E. M.; Méplan, C.; Schomburg, L.; Evelo, C. ... and Brigelius-Flohé, R. (2009). Four selenoproteins, protein biosynthesis, and Wnt signalling are particularly sensitive to limited selenium intake in mouse colon. Mol Nutr Food Res., 53(12):

1561-1572. https://doi.org/10.1002/mnfr.200900105 
Kohshahi, A.J.; Sourinejad, I.; Sarkheil, M. and Johari, S.A. (2019). Dietary cosupplementation with curcumin and different selenium sources (nanoparticulate, organic, and inorganic selenium): influence on growth performance, body composition, immune responses, and glutathione peroxidase activity of rainbow trout (Oncorhynchus mykiss). Fish Physiol. Biochem., 45(2): 793-804. https://doi.org/10.1007/s10695-018-0585-y

Köllner, B.; Wasserrab, B.; Kotterba, G. and Fischer, U. (2002). Evaluation of immune functions of rainbow trout (Oncorhynchus mykiss)-how can environmental influences be detected?. Toxicol. Lett., 131(1-2): 83-95. https://doi.org/10.1016/S0378-4274(02)00044-9

Kumar, N.; Krishnani, K. K. and Singh, N. P. (2018). Comparative study of selenium and selenium nanoparticles with reference to acute toxicity, biochemical attributes, and histopathological response in fish. Environ. Sci. Pollut. Res., 25(9): 8914-8927. https://doi.org/10.1007/s11356-017-1165-x

Lammel, T. and Sturve, J. (2018). Assessment of titanium dioxide nanoparticle toxicity in the rainbow trout (Onchorynchus mykiss) liver and gill cell lines RTL-W1 and RTgill-W1 under particular consideration of nanoparticle stability and interference with fluorometric assays. NanoImpact., 11: 1-19. https://doi.org/10.1016/j.impact.2018.01.001

Lee, S.; Nambi, R.W.; Won, S.; Katya, K. and Bai, S.C. (2016). Dietary selenium requirement and toxicity levels in juvenile Nile tilapia, Oreochromis niloticus. Aquaculture, 464:

153-158. https://doi.org/10.1016/j.aquaculture.2016.06.027

Liu, J.; Zhang, K.; Ren, X.; Luo, G. and Shen, J. (2004). Bioimprinted protein exhibits glutathione peroxidase activity. Analytica chimica acta., 504(1): 185-189. https://doi.org/10.1016/S0003-2670(03)00763-3

Lulijwa, R.; Alfaro, A.C.; Merien, F.; Burdass, M.; Venter, L. and Young, T. (2019). In vitro immune response of chinook salmon (Oncorhynchus tshawytscha) peripheral blood mononuclear cells stimulated by bacterial lipopolysaccharide. Fish shellfish immunol., 94: 190-198. https://doi.org/10.1016/j.fsi.2019.09.003

Madigan, M.T. and Martinko, J. (2005). Brock Biology of Microorganisms, 11th Ed. Prentice Hall.

Majumdar, T.; Ghosh, D.; Datta, S.; Sahoo, C.; Pal, J. and Mazumder, S. (2007). An attenuated plasmid-cured strain of Aeromonas hydrophila elicits protective immunity in Clarias batrachus L. Fish shellfish immunol., 23(1): 222-230. https://doi.org/10.1016/j.fsi.2006.10.011

Mansour, A.T.E.; Goda, A.A.; Omar, E.A.; Khalil, H.S. and Esteban, M. Á. (2017). Dietary supplementation of organic selenium improves growth, survival, antioxidant and immune status of meagre, Argyrosomus regius, juveniles. Fish Shellfish Immunol., 68: 516-524. https://doi.org/10.1016/j.fsi.2017.07.060 
Maurer, H.R. (2011). Disc electrophoresis and related techniques of polyacrylamide gel electrophoresis. Walter de Gruyter. Berlin, New York.

Neamat-Allah, A.N.; Mahmoud, E. A. and Abd El Hakim, Y. (2019). Efficacy of dietary Nano-selenium on growth, immune response, antioxidant, transcriptomic profile and resistance of Nile tilapia, Oreochromis niloticus against Streptococcus iniae infection. Fish Shellfish Immunol., 94: 280-287. https://doi.org/10.1016/j.fsi.2019.09.019

Nikapitiya, C.; Dananjaya, S.H.S.; De Silva, B.C.J.; Heo, G.J.; Oh, C.; De Zoysa, M. and Lee, J. (2018). Chitosan nanoparticles: a positive immune response modulator as display in zebrafish larvae against Aeromonas hydrophila infection. Fish Shellfish Immunol., 76: 240-246. https://doi.org/10.1016/j.fsi.2018.03.010

Ortuno, J.; Esteban, M.A. and Meseguer, J. (2001). Effects of short-term crowding stress on the gilthead seabream (Sparus aurata L.) innate immune response. Fish Shellfish Immunol., 11(2): 187-197. https://doi.org/10.1006/fsim.2000.0304

Parveen, N. and Shadab, G.G.H.A. (2012). Cytogenetic evaluation of cadmium chloride on Channa punctatus. J. Environ. Biol., 33(3): 663-666.

Prokisch, J.; Széles, É.; Kovács, B.; Daróczy, L. and Zommara, M. (2008). Formation of metal selenium nanospheres in bacteria: is it a possible detoxification mechanism?. Cereal Research $\quad$ Communications, 36: 947-950. https://www.jstor.org/stable/90002862

Prokisch, J.; Sztrik, A.; Babka, B.; Eszenyi, P.; Pardi, J.; Mika, Z. and Zommara, M. (2011). Novel Fermentation technology for production of selenium nanospheres (Lactomicrosel®) and its testing for feed and food applications. In 2nd International conference on selenium in the environment and human health china-singapore suzhou industrial park, Suzhou, China (23-28 October).

Public Health Agency of Canada (2010). The Honourable Leona Aglukkaq, P.C., M.P. Minister of Health.

Qian, F.; Misra, S. and Prabhu, K. S. (2019). Selenium and selenoproteins in prostanoid metabolism and immunity. Crit. Rev. Biochem. Mol. Biol., 54(6): 484516. https://doi.org/10.1080/10409238.2020.1717430

Reeves, M.A. and Hoffmann, P.R. (2009). The human selenoproteome: recent insights into functions and regulation. Cell. Mol. Life Sci., 66(15): 2457-2478. https://doi.org/10.1007/s00018-009-0032-4

Saber, S.; Khalil, R.M.; Abdo, W.S.; Nassif, D. and El-Ahwany, E. (2019). Olmesartan ameliorates chemically-induced ulcerative colitis in rats via modulating NFkB and Nrf-2/HO-1 signaling crosstalk. Toxicol. Appl. Pharmacol. 364: 120132. https://doi.org/10.1016/j.taap.2018.12.020

Saffari, S.; Keyvanshokooh, S.; Zakeri, M.; Johari, S.A.; Pasha-Zanoosi, H. and Mozanzadeh, M.T. (2018). Effects of dietary organic, inorganic, and nanoparticulate selenium sources on growth, hemato-immunological, and serum 
biochemical parameters of common carp (Cyprinus carpio). Fish Physiol. Biochem., 44(4): 1087-1097. https://doi.org/10.1007/s10695-018-0496-y

Sarkar, B.; Bhattacharjee, S.; Daware, A.; Tribedi, P.; Krishnani, K.K. and Minhas, P.S. (2015). Selenium nanoparticles for stress-resilient fish and livestock. Nanoscale Res. Lett., 10(1): 371. https://doi.org/10.1186/s11671-015-107 3-2

Schaperclaus, W.; Kulow, H. and Schreckenbach, K. (1992). Fish disease. Rotterdam, the Netherlands: A.A. Balkema, pp.101-105.

Sherif, A.H.; Alsokary, E.T. and Esam, H.A. (2019). Assessment of titanium dioxide nanoparticle as treatment of Aeromonas hydrophila infection in Oreochromis niloticus. J HELL VET MED SOC., 70(3): 1697-1706. https://doi.org/10.12681/ jhvms.21796

Sherif, A.H.; Gouda, M.; Alsokary, E.T. and Elseify, M. (2021)b. Lactobacillus plantarum enhances immunity of Nile tilapia Oreochromis niloticus challenged with Edwardsiella tarda. Aquac. Res., 52(3): 1001-1012. https://doi.org/ 10.1111/are.14955

Sherif, A.H.; Gouda, M.; Darwish, S. and Abdelmohsin, A. (2021)a. Prevalence of antibiotic-resistant bacteria in freshwater fish farms. Aquac. Res., 52(5): 20362047. https://doi.org/10.1111/are.15052

Shimohashi, N.; Nakamuta, M.; Uchimura, K.; Sugimoto, R.; Iwamoto, H.; Enjoji, M. and Nawata, H. (2000). Selenoorganic compound, ebselen, inhibits nitric oxide and tumor necrosis factor- $\alpha$ production by the modulation of Jun-N-terminal kinase and the NF-kb signaling pathway in rat Kupffer cells. J. Cell. Biochem., 78(4): 595-606. https://doi.org/10.1002/1097-4644(20000915) 78:4<595::AID-JCB9>3.0.CO;2-B

Shobana, C.; Rangasamy, B.; Poopal, R.K.; Renuka, S. and Ramesh, M. (2018). Green synthesis of silver nanoparticles using Piper nigrum: tissue-specific bioaccumulation, histopathology, and oxidative stress responses in Indian major carp Labeo rohita. Environ. Sci. Pollut. Res., 25(12): 11812-11832. https://doi.org/10.1007/s11356-018-1454-Z

Song, X.; Zhao, J.; Bo, Y.; Liu, Z.; Wu, K. and Gong, C. (2014). Aeromonas hydrophila induces intestinal inflammation in grass carp (Ctenopharyngodon idella): an experimental model. Aquaculture, 434: 171-178. https://doi.org/10.1016/ j.aquaculture.2014.08.015

SPSS (2004). "Statistical and Package for Social Science, SPSS for Windows Release 14.0.0, 19 June, 2004.” Standard Version. copyright SPSS Inc., pp. 1989-2004.

Suvarna, K.S.; Layton, C. and Bancroft, J. D. (2012). Bancroft's Theory and Practice of Histological Techniques: Expert Consult: Online and Print. Elsevier Health Sciences.

Suzuki, Y.; Hashiura, Y.; Matsumura, K.; Matsukawa, T.; Shinohara, A. and Furuta, N. (2010). Dynamic pathways of selenium metabolism and excretion in 
mice under different selenium nutritional statuses. Metallomics., 2(2): 126-132. DOI: $10.1039 / \mathrm{B} 915816 \mathrm{~B}$

Tonguthai, K.; Chinabut, S.; Somsiri, T.; Chanratchakool, P. and Kanchanakhan, S. (1999). Diagnostic procedures for finfish diseases. Aquatic Animal Health Research Institute, Bangkok, Thailand, 23.

Wang, H.; Zhang, J. and Yu, H. (2007). Elemental selenium at nano size possesses lower toxicity without compromising the fundamental effect on selenoenzymes: comparison with selenomethionine in mice. Free Radic. Biol. Med., 42(10): 15241533. https://doi.org/10.1016/j.freeradbiomed.2007.02.013

Wang, J.; Li, Y.; Lai, K.; Zhong, Q.; Demin, K.A.; Kalueff, A.V. and Song, C. (2020). High-glucose/high-cholesterol diet in zebrafish evokes diabetic and affective pathogenesis: The role of peripheral and central inflammation, microglia and apoptosis. Prog. Neuropsychopharmacol. Biol. Psychiatry., 96: 109752. https://doi.org/10.1016/j.pnpbp.2019.109752

Watanabe, T.; Kiron, V. and Satoh, S. (1997). Trace minerals in fish nutrition. Aquaculture, 151(1-4): 185-207. https://doi.org/10.1016/S0044-8486(96) $\underline{01503-7}$

Weichsellbaum, T.E. (1946). Determination of total proteins. Am. J. Clin. Pathol., 7: 40.

Xia, I.F.; Cheung, J.S.; Wu, M.; Wong, K.S.; Kong, H.K.; Zheng, X.T.; Wong, K.H. and Kwok, K. W. (2019). Dietary chitosan-selenium nanoparticle (CTS-SeNP) enhance immunity and disease resistance in zebrafish. Fish shellfish immunol., 87: 449-459. https://doi.org/10.1016/j.fsi.2019.01.042

Yawata, A.; Adachi, M.; Okuda, H.; Naishiro, Y.; Takamura, T.; Hareyama, M.; Takayama, S.; Reed, J.C. and Imai, K. (1998). Prolonged cell survival enhances peritoneal dissemination of gastric cancer cells. Oncogene., 16(20): 2681-2686. https://doi.org/10.1038/sj.onc. 1201792

Yu, Y.; Zhang, F.; Lu, D. and Zhang, H. (2014). Selenium bioavailability from shrimps (Penaeus vannamei Boone) and its effect on the metabolism of phospholipid and cholesterol ester., J. Funct. Foods., 6: 186-195. https://doi.org/10.1016/j.jff. 2013. $\underline{10.005}$

Zhang, Z.; Li, S.; Jiang, H.; Liu, B.; Lv, Z.; Guo, C. and Zhang, H. (2017). Effects of selenium on apoptosis and abnormal amino acid metabolism induced by excess fatty acid in isolated rat hepatocytes. Mol Nutr Food Res., 61(9): 1700016. https://doi.org/10.1002/mnfr.201700016

Zhu, L.; Han, D.; Zhu, X.; Yang, Y.; Jin, J.; Liu, H. and Xie, S. (2017). Dietary selenium requirement for on-growing gibel carp (Carassius auratus gibelio var. CAS III). Aquac. Res., 48(6): 2841-2851. https://doi.org/10.1111/are.13118

Zommara, M.A. (2007). Production of organic selenium enriched yoghurt. J. Agricult. Res. KFS. Univ. 31: 820-839. 